\title{
Nutritional evaluation of different sources of nitrogen on digestible nutrient intake, nitrogen balance and production of rumen metabolites in growing Yankasa sheep
}

\author{
M. Abubakar ${ }^{1,2 *}$, T. A. Adegbola ${ }^{1}$, M. M. Abubakar ${ }^{1}$, Y. Shehu ${ }^{1}$, M. B. Ngele $^{1}$ \\ and D. J. U. Kalla ${ }^{1}$ \\ ${ }^{1}$ Animal Production Program, Abubakar Tafawa Balewa University, PMB 0248, Bauchi, \\ Nigeria; ${ }^{2}$ Department of Biological Sciences, School of The Environment and Society, \\ Swansea University, Singleton Park SA2 8PP, Swansea, West Glamorgan, United Kingdom
}

\begin{abstract}
A study was conducted to evaluate digestible nutrient intake, nitrogen balance and rumen metabolites in twenty growing Yankasa rams fed urea and /or sundried broiler litter (SDBL) as a partial or complete replacement for cotton seed cake (CSC) in diets for 90 days. The diets were: 1(CSC; control), 2(urea), 3(urea/SDBL), 4(CSC/urea) and 5(CSC/SDBL). The results indicated difference $(\mathrm{P}<0.05)$ in $\mathrm{DM}$ intake across diets, with animals fed CSC, urea and CSC/urea having the highest values (543.1, 523.4 and $483.6 \mathrm{~g} /$ day respectively), while those fed urea/SDBL and CSC/SDBL ((459.5 and 424.3g/day respectively) had the lowest feed intake. Mean digestible $\mathrm{CP}$ intake differed $(\mathrm{P}<0.001)$ across the diets and the values were higher for rams fed CSC and urea $(75.7$ and $72.7 \mathrm{~g} /$ day) and lowest for those on CSC/SDBL (49.0g/day). However, mean digestible ADF intake was similar among the diets. A positive nitrogen balance was observed for all animals across the treatments, with significant $(\mathrm{P}<0.05)$ differences between treatments ranging from $4.3 \mathrm{~g}$ /day for rams fed CSC/SDBL to $7.5 \mathrm{~g}$ /day for those on urea. $\mathrm{pH}$ decreased with time after feeding. At $3 \mathrm{hrs}$ post feeding, $\mathrm{pH}$ was highest $(\mathrm{P}<0.01)$ for rams fed $\mathrm{CSC} / \mathrm{SDBL}$ and CSC/urea (6.9) and lowest for those on urea alone (6.1) and CSC (6.2). There was a gradual increase in the concentrations of both rumen ammonia-N (RAN) and total volatile fatty acids (VFA) after feeding. Rams fed urea and urea/SDBL (37.5 and $34.2 \mathrm{mg} / 100 \mathrm{ml}$ respectively) had the highest $(\mathrm{P}<0.001)$ RAN concentration $3 \mathrm{hrs}$ after feeding, while those on the other diets recorded the lowest. On the other hand, rams fed CSC/SDBL $(13.1 \mathrm{mmol} / 100 \mathrm{ml})$ had the highest $(\mathrm{P}<0.001)$ VFA concentrations while those on urea the lowest $(10.5 \mathrm{mmol} / 100 \mathrm{ml})$. It was concluded from this study that diets containing urea and CSC/urea fed to Yankasa sheep gave results comparable to those fed cotton seed cake (control), which are better than for those fed sundried broiler litterbased diets in terms of digestible nutrients intake, positive nitrogen balance and production of adequate rumen ammonia-N. However, rams fed CSC/SDBL had a better concentration of total volatile fatty acids of rumen fluid after feeding.
\end{abstract}

Keywords: Nitrogen sources, nutrient intake, nitrogen balance, rumen metabolites, Yankasa sheep

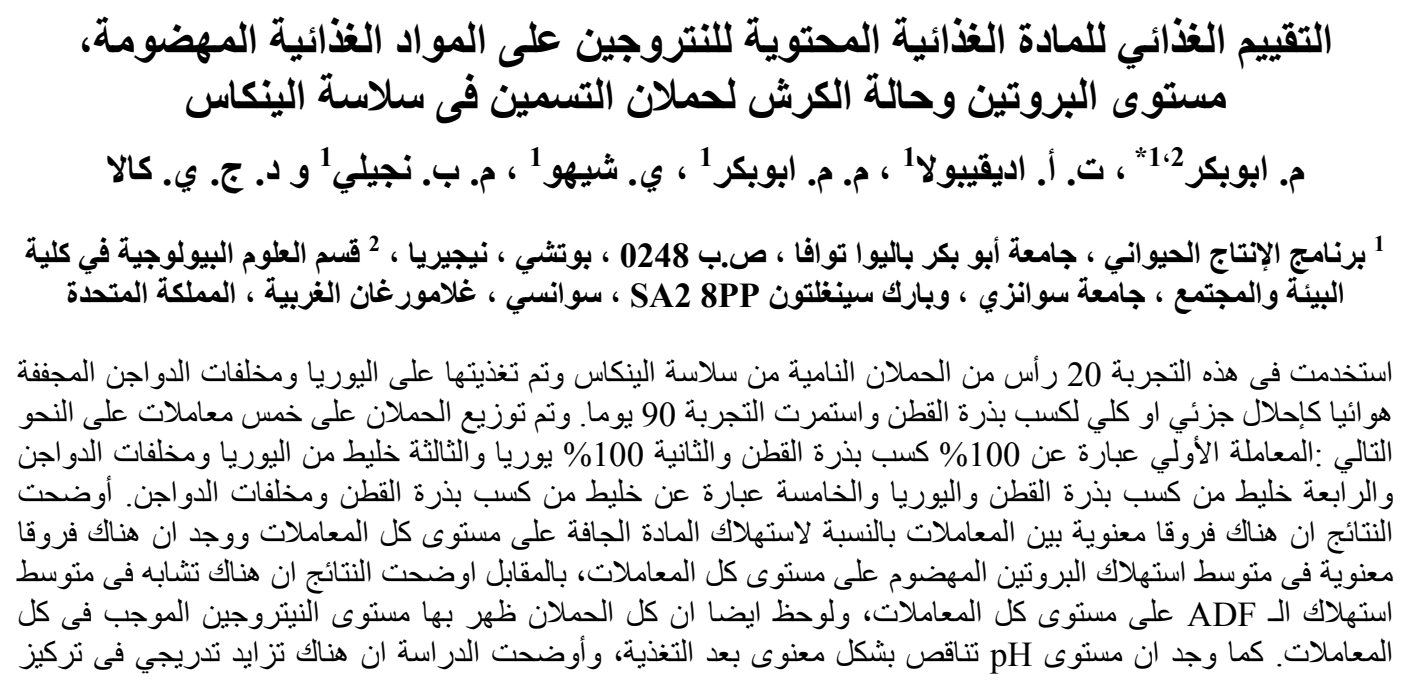

* Corresponding Author Email:mabubakarkobi@yahoo.co.uk 


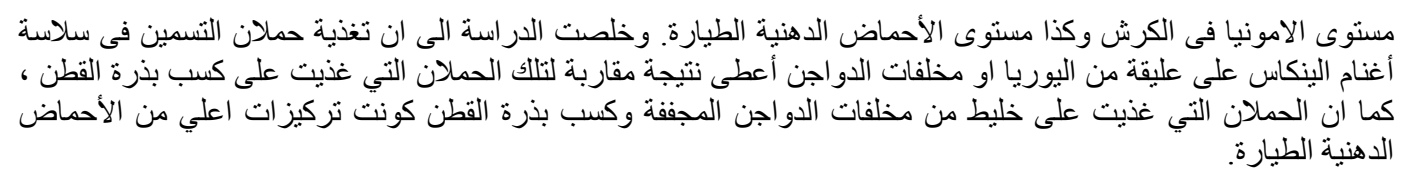

\section{Introduction}

The problem of low animal protein intake in livestock of Africa and particularly Nigeria is critical and forms a real challenge to animal scientists and policy makers. The primary concern of animal nutritionists, is to balance the nutrients that provide the major building blocks for tissue synthesis (Leng, 1990). Both man and farm animals however competitively share the conventional feedstuffs. Therefore, as a result of spiralling costs and dwindling supplies of conventional feed resources such as cotton seed cake, it has become imperative to search for cheaper feed ingredients that can provide affordable livestock nutrients to farmers in the tropics.

Urea supplementation to low quality feeds has been shown to increase the rumen availability of nitrogen which in turn increase the rumen degradation and energy intake by ruminants (Abebe et al., 2004). On the other hand, poultry house waste is a rich source of protein ranging between 14 and $30 \%$ crude protein, of which $40-50 \%$ is true protein that can be utilized by ruminants to produce high quality meat and milk (Adegbola, 1998). The nitrogen in poultry waste can be utilized up to ten times more efficiently when recycled through ruminants as a feed than as a fertilizer (Smith and Wheeler, 1979).

The present study aimed at assessing the effects varying levels of urea and / or sundried broiler litter as a partial or complete replacement for cotton seed cake in diets on digestible nutrient intake, nitrogen balance and production of rumen metabolites in growing Yankasa sheep.

\section{Materials and Methods Study area}

The study was conducted at the Abubakar Tafawa Balewa University
Teaching and Research farm in Bauchi, which lies along latitude $10^{\circ} 17^{1}$ North and longitude $8^{\circ} 49^{\prime}$ East in the Northern Guinea Savannah ecological zone of Nigeria.

\section{Animals and their management}

Twenty young Yankasa rams with an average weight of $16.54 \pm 0.54 \mathrm{~kg}$ and between 1 and $1 / 2$ years in age were used for the experiment. Before the start of the experiment, the animals were quarantined for four weeks during which they were dewormed with albendazole $(2.5 \%$ oral solution) and dipped in Diazintol to guard against ectoparasites. They were treated with Oxytetran long acting broad-spectrum antibiotic. The animals were randomly divided into five groups of four animals each and kept in individual pens, which had been washed and disinfected. The pens had concrete floors and were well ventilated. The pens and feeding containers were cleaned daily.

\section{Experimental diets and animal feeding}

Poultry (broiler) litter was obtained from the Abubakar Tafawa Balewa University Poultry farm in Bauchi. The litter was thoroughly raked to remove foreign and/or caked materials and sun dried for about three weeks. The litter termed sundried broiler litter was milled, sieved and stored for use in preparation of the experimental diets.

Five diets $(16 \% \quad \mathrm{CP})$ were formulated using cotton seed cake (CSC), sundried broiler litter (SDBL), urea, maize offal (MO) and groundnut haulms (GNH). The CSC, SDBL, urea, and MO were milled and mixed with chopped groundnut haulms. The diets were formulated in such a way that CSC was the control diet, which was partially or completely replaced by urea and / or SDBL in the other treatments 
as follows: 1 (CSC; control), 2 (urea), 3 (urea/SDBL), 4 (CSC/urea) and 5 (CSC/SDBL) respectively.

The rams were allowed a 14 day adaptation period. During the experiment, which lasted for 90 days, the rams were offered their respective diets every morning at about $0800 \mathrm{hrs}$. Total daily diet allowance was adjusted on the basis of the previous day's intake. The left over feeds of the previous day were weighed and discarded before adding fresh feeds. Rams were provided fresh drinking water in graduated plastic buckets. The ingredients and chemical composition (DM basis) of the experimental diets are shown in Tables 1 and 2.

Table 1. Ingredients composition of diets fed to animals.

\begin{tabular}{llllll}
\hline CSC/SDBL & CSC/Urea & $\begin{array}{l}\text { Diets } \\
\text { Urea/SDBL }\end{array}$ & Urea & CSC & Composition \\
\hline 40.00 & 40.00 & 40.00 & 40.00 & 40.00 & Groundnut haulms \\
32.88 & 45.15 & 43.18 & 55.45 & 34.85 & Maize offal \\
11.33 & 11.33 & - & - & 22.65 & Cotton seed cake \\
- & 1.03 & 1.03 & 2.05 & - & Urea \\
13.29 & - & 13.29 & - & - & Sundried broiler litter \\
2.00 & 2.00 & 2.00 & 2.00 & 2.00 & Bone meal \\
0.50 & 0.50 & 0.50 & 0.50 & 0.50 & Salt lick \\
100.00 & 100.00 & 100.00 & 100.00 & 100.00 & Total \\
\hline
\end{tabular}

$=$ Cotton seed cake $\quad$ SDBL $=$ Sundried broiler litter

Table 2. Chemical composition of diets fed to animals (\%).

\begin{tabular}{llllll}
\hline CSC/SDBL & CSC/Urea & $\begin{array}{l}\text { Diets } \\
\text { Urea/SDBL }\end{array}$ & Urea & CSC & Composition $^{\mathbf{1}}$ \\
\hline 95.46 & 93.56 & 94.97 & 95.31 & 94.82 & Dry matter \\
86.41 & 87.51 & 88.78 & 84.58 & 85.74 & Organic matter \\
16.65 & 16.40 & 16.21 & 16.10 & 16.47 & Crude protein \\
32.48 & 31.10 & 37.61 & 32.46 & 35.42 & NDF \\
29.59 & 24.42 & 27.10 & 18.47 & 20.51 & ADF \\
\hline
\end{tabular}

${ }^{1}$ All values on DM basis except for dry matter

$\mathrm{CSC}=$ Cotton seed cake $\quad$ SDBL $=$ Sundried broiler litter

\section{Rumen fluid collection}

Rumen fluid was collected from each ram using stomach suction tube before and after feeding during the seventh week of the experiment into a sterilized bottle. The $\mathrm{pH}$ was immediately recorded using an AGB-75 laboratory pH-meter. The rumen fluid was strained through two layers of surgical gauge to remove particulate matter before the addition of $0.05 \mathrm{~N}$ sulphuric acid. Samples were analysed for total volatile fatty acid (VFA) and Rumen ammonia-N. Total VFA was determined according to Ziolecki and
Kwaitkowska (1975) and Rumen ammonia-N concentration by the method of Mgheni et al. (1994).

\section{Nitrogen balance study}

An $\mathrm{N}$ balance study was conducted at the end of the experiment. Each ram was transferred into a metabolism cage equipped for separate collection of faeces and urine. The rams were maintained on their respective treatment diets and allowed a 7-day adjustment period to the cages before faecal and urine collection for seven days. The quantity of feed offered, 
feed residue, faeces and urine from each ram was determined. Faeces voided daily by each were collected in polythene bags, weighed and oven-dried at $65^{\circ} \mathrm{C}$ for 24 hours. At the end of collection period, all samples from each ram were bulked, thoroughly mixed and a $10 \%$ sub sample taken for chemical analysis. For each ram, total daily urine output was collected into plastic containers to which $0.05 \mathrm{~N}$ sulphuric acid had been added to prevent $\mathrm{N}$ loss by volatilization (Chen and Gomez, 1992). After recording the volume, a $10 \%$ aliquot sample was taken daily into labeled sample bottles of each animal's week collection which was taken to the laboratory for $\mathrm{N}$ analysis.

\section{Data collection}

During the experiment, residual feed and water were weighed daily to determine total feed and water intake of each ram. Weight of individual animal was measured at the onset of the trial and subsequently on weekly basis throughout the 90 day period.

\section{Experimental design}

The experimental design was a completely randomized design (Steel and Torrie, 1980), with five treatments of four animals each.

\section{Chemical analysis}

The dry matter content of the experimental diets and faecal samples was determined by drying at $65^{\circ} \mathrm{C}$ for 48 hours in an oven. Ash was measured by igniting the samples in a muffle furnace at $500^{\circ} \mathrm{C}$ for 4 hours. Nitrogen (or CP) content was determined by the automated Kjeldahl method (AOAC, 1990). Neutral detergent fibre (NDF) and acid detergent fibre (ADF) were determined by the method described by Goering and Van Soest (1970). Urine were analysed for total $\mathrm{N}$ according to the methods of Chen and Gomes (1992).

\section{Statistical analysis}

Data collected were subjected to Analysis of variance (ANOVA) as described by Steel and Torrie (1980) using the General Linear Model (SPSS for Windows) procedure of SAS (2000) (Version 8.2), SAS Institute Incorporated, Cary, NC, USA. Where significant differences existed between means, least significant difference (LSD) was used to separate them.

\section{Ethical consideration}

All international and local ethical and animal welfare regulations were strictly observed to minimize any sufferings by the experimental animals during this study.

\section{Results and Discussion}

The effects of including urea and / or SDBL as a partial or complete replacement for CSC in the diets of rams on digestible nutrients intake and daily weight gain (g/day) of Yankasa rams are shown in Table 3. Dry matter intake for animals fed CSC, urea and their combination (543, 523 and 484g/day respectively) were similar and higher $(\mathrm{P}<0.05)$ than those on SDBL based diets. Decreased DMI with high levels of dried poutry waste has been reported in sheep (Rankins et al., 1993), due to reduced palatability of the diets with increasing levels of poutry waste. Digestible DM intake was higher $(\mathrm{P}<0.01)$ for animals fed CSC and urea alone (317 and 290g/day respectively) and lowest for those on urea/SDBL (259g/day) and CSC/urea (252g/day), which were similar but also higher than for those on CSC/SDBL diet $(207 \mathrm{~g} /$ day). The mean daily digestible CP intake differed $(\mathrm{P}<0.001)$ among the treatments, with values ranging from $49 \mathrm{~g}$ for rams fed CSC/SDBL to $76 \mathrm{~g}$ for those on CSC alone. Chesworth (1992) gave the digestible $\mathrm{CP}$ intake recommended for sheep gaining $100 \mathrm{~g} /$ day to be $43 \mathrm{~g} /$ day while those gaining $50 \mathrm{~g} /$ day was $29 \mathrm{~g} /$ day. 
In the current study, rams on the CSC diet, which gained $100 \mathrm{~g} /$ day, had a higher digestible CP intake value of $76 \mathrm{~g} /$ day compared to the recommended value of $43 \mathrm{~g} /$ day. Similarly, rams with the least daily body weight gain of $53 \mathrm{~g} /$ day recorded a digestible CP intake of $49 \mathrm{~g} /$ day. This was also higher than the recommended digestible $\mathrm{CP}$ intake of $29 \mathrm{~g} /$ day for animals gaining $50 \mathrm{~g} /$ day. A likely explanation for the higher digestible $\mathrm{CP}$ intake with corresponding lower daily weight gain values could be due to the higher $\mathrm{N}$ loss in urine (4.1-4.3g/day).
Digestible NDF intake of the rams showed lower $(\mathrm{P}<0.001)$ values for rams fed CSC/SDBL (74g/day), while those on CSC and urea diets (114 and $116 \mathrm{~g} /$ day respectively) the highest. Rams on urea/SDBL and CSC/urea had levels of 85 and 91g/day respectively. Digestible NDF intake was related to digestible DM intake. However, the results of digestible ADF intake indicated that all rams consumed equal amounts of digestible ADF irrespective of the source and type of protein in the diets.

Table 3. Nutrient intake and daily weight gain (g/day) of Yankasa rams fed urea and/or sundried broiler litter as a partial or complete replacement for cotton seed cake.

\begin{tabular}{|c|c|c|c|c|c|c|}
\hline \multirow[t]{2}{*}{ SEM } & \multicolumn{6}{|c|}{ Diets } \\
\hline & CSC/SDBL & CSC/Urea & Urea/SDBL & Urea & CSC & \\
\hline 12.85 & $424^{\mathrm{c}}$ & $484^{\mathrm{ab}}$ & $460^{\mathrm{bc}}$ & $523^{\mathrm{ab}}$ & $543^{\mathrm{a}}$ & DMI \\
\hline 4.55 & $53^{\mathrm{c}}$ & $68^{\mathrm{b}}$ & $60^{\mathrm{bc}}$ & $96^{\mathrm{a}}$ & $100^{\mathrm{a}}$ & DWG \\
\hline 10.35 & $207^{\mathrm{c}}$ & $252^{\mathrm{b}}$ & $259^{\mathrm{b}}$ & $290^{\mathrm{a}}$ & $317^{\mathrm{a}}$ & DDMI \\
\hline 2.64 & $49^{\mathrm{d}}$ & $64^{\mathrm{b}}$ & $57^{\mathrm{c}}$ & $73^{\mathrm{a}}$ & $76^{\mathrm{a}}$ & DCPI \\
\hline 3.97 & $74^{\mathrm{c}}$ & $91^{\mathrm{b}}$ & $85^{\mathrm{b}}$ & $116^{\mathrm{a}}$ & $114^{\mathrm{a}}$ & DNDFI \\
\hline 1.47 & 58 & 59 & 54 & 59 & 54 & DADFI \\
\hline DMI & \multicolumn{6}{|c|}{ 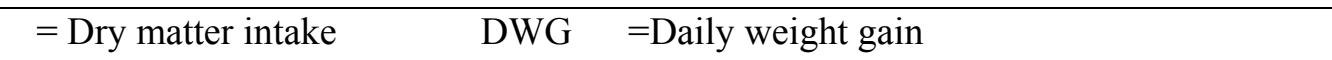 } \\
\hline DDMI & \multicolumn{6}{|c|}{$=$ Digestible DM intake DCPI $=$ Digestible $\mathrm{CP}$ intake } \\
\hline DNDFI & \multirow{2}{*}{\multicolumn{6}{|c|}{$=$ Digestible NDF intake }} \\
\hline SEM & & \multirow{2}{*}{\multicolumn{5}{|c|}{$=$ Standard error of mean }} \\
\hline SDBL & $=$ Sundried broi & & & & & \\
\hline
\end{tabular}

The effects of including urea and / or SDBL as a partial or complete replacement for CSC in the diets of rams on $\mathrm{N}$ intake and output are shown in Table 4. Mean values for daily $\mathrm{N}$ intake were different $(\mathrm{P}<0.01)$ across the dietary treatments and ranged from $11.2 \mathrm{~g}$ for rams on $\mathrm{CSC} / \mathrm{SDBL}$ diets to $13.9 \mathrm{~g}$ for those fed $\mathrm{CSC}$ alone. $\mathrm{N}$ intake in the current study is much higher than that obtained by Adu and Lakpini (1983) for Yankasa sheep (9.26 $10.78 \mathrm{~g} /$ day) even though total DMI was higher in the latter study (631-778g/day). This could possibly be because the diets in current study contained higher CP (16\%) levels compared to the $12 \%$ in the other study. NI was observed to be lowest for animals on all SDBL-based diets in the present study. This conforms to an earlier observation by Rankins et al., 1993, where NI decreased as the proportion of dried poultry waste in the supplementary diet increased. This might also be due to the reported pattern of DM intake, which was lower for the SDBL based diets in the current study. Faecal $\mathrm{N}$ values were highly different $(\mathrm{P}<0.001)$ among the treatments. There were differences in faecal $\mathrm{N}$, which indicated that rams on urea and its combination with SDBL excreted lower N than those on the others. This may suggest a higher overall digestibility and absorption of $\mathrm{N}$ from these supplements compared to the other experimental dietary treatments. Urinary $\mathrm{N}$ values were similar across the diets, ranging from $4.1 \mathrm{~g} /$ day for rams fed $\mathrm{CSC} /$ urea and $\mathrm{CSC} / \mathrm{SDBL}$ to $5.1 \mathrm{~g} /$ day for those fed CSC alone. The 
values of urinary $\mathrm{N}$ in the present study fall within the range of 3.3 to $8.8 \mathrm{~g} /$ day reported by Osuhor et al. (1991) for Yankasa sheep fed graded levels of protein concentrates. Total $\mathrm{N}$ output was similar across treatments and ranged from $4.2 \mathrm{~g} /$ day for rams fed CSC/urea to $8.0 \mathrm{~g} /$ day for those on CSC diet. $\mathrm{N}$ retained (balance) was positive across the treatments and the values differed $(\mathrm{P}<0.05)$ among treatments. Rams fed CSC/SDBL recorded the lowest $(\mathrm{P}<0.05)$ value $(4.3 \mathrm{~g} /$ day $)$, while those on urea alone the highest $(7.5 \mathrm{~g} /$ day). Urea supplementation increased sugar availability from increased cellulose degradation (Kozloski et al., 2000; Pan et al., 2003), consequently increasing amino acid synthesis by rumen bacteria. A higher proportion of these amino acids could have entered the small intestine increasing amino acid absorption and $\mathrm{N}$ retention by rams (Kozloski et al., 2006a). The positive $\mathrm{N}$ balance in this study indicates that $\mathrm{N}$ intake was able to yield an equitable level of intake of $\mathrm{N}$ to ensure sufficient positive balance as observed earlier (Adeleye and Fasetan, 1997). Generally, the $N$ balance in this study is similar to $6.10 \mathrm{~g}$ /day (Murthy et al., 1996), but higher than $2.51 \mathrm{~g} /$ day (Adamu et al., 1996) reported for sheep. Nitrogen retained, as percent of $\mathrm{N}$ intake differed $(\mathrm{P}<0.05)$ among treatments, with values being highest in rams fed urea alone $(54.7 \%)$ and lowest for those on CSC/SDBL (38.6\%). Amount of $\mathrm{N}$ absorbed differed $(\mathrm{P}<0.001)$ among treatments, with rams fed $\mathrm{CSC} / \mathrm{SDBL}$ having the lowest values compared to those on other diets.

Table 4. Nitrogen utilization in growing Yankasa rams fed urea and/or sundried broiler litter as a partial or complete replacement for cotton seed cake (g/day).

\begin{tabular}{lllllll}
\hline SEM & CSC/SDBL & CSC/Urea & $\begin{array}{l}\text { Diets } \\
\text { Urea/SDBL }\end{array}$ & Urea & CSC & \\
\hline 0.30 & $11.2^{\mathrm{c}}$ & $12.9^{\mathrm{a}}$ & $11.6^{\mathrm{b}}$ & $13.7^{\mathrm{a}}$ & $13.9^{\mathrm{a}}$ & N intake \\
0.94 & $2.8^{\mathrm{a}}$ & $2.1^{\mathrm{b}}$ & $1.7^{\mathrm{b}}$ & $1.9^{\mathrm{b}}$ & $3.0^{\mathrm{a}}$ & Faecal N \\
0.68 & 4.1 & 4.1 & 4.1 & 4.3 & 5.1 & Urinary N \\
0.25 & 6.9 & $4.9^{\mathrm{c}}$ & 5.8 & 6.2 & $8.0^{\mathrm{a}}$ & Total N Output \\
0.29 & $4.3^{\mathrm{c}}$ & $6.7^{\mathrm{a}}$ & $5.8^{\mathrm{b}}$ & $7.5^{\mathrm{a}}$ & $5.9^{\mathrm{b}}$ & N Retained \\
1.37 & $38.6^{\mathrm{c}}$ & $52.2^{\mathrm{a}}$ & $50.2^{\mathrm{b}}$ & $54.7^{\mathrm{a}}$ & $42.2^{\mathrm{c}}$ & N Retained, \% \\
0.38 & $8.4^{\mathrm{c}}$ & $10.8^{\mathrm{a}}$ & $9.9^{\mathrm{b}}$ & $11.8^{\mathrm{a}}$ & $10.9^{\mathrm{a}}$ & N Absorbed \\
1.14 & $75.2^{\mathrm{b}}$ & $83.9^{\mathrm{a}}$ & $85.6^{\mathrm{a}}$ & $86.2^{\mathrm{a}}$ & $78.6^{\mathrm{b}}$ & N Absorbed, \% \\
\hline CSC
\end{tabular}

$\mathrm{CSC}=$ Cotton seed cake

SDBL $=$ Sundried broiler litter

Table 5 shows the rumen fluid $\mathrm{pH}$, ammonia $\mathrm{N}$ and total volatile fatty acids (VFA) of Yankasa rams fed urea and / or SDBL as a partial or complete replacement for $\mathrm{CSC}$ in diets. The $\mathrm{pH}$ (before feeding) ranged from 7.2 for rams on $\mathrm{CSC}$ diet to 7.9 for those on urea/SDBL diet. The $\mathrm{pH}$ decreased with time after feeding. At $3 \mathrm{hrs}$ post feeding, $\mathrm{pH}$ was highest $(\mathrm{P}<0.01)$ for $\mathrm{CSC} / \mathrm{SDBL}$ and CSC/urea (6.9) and lowest for urea alone diet (6.1) and CSC (6.2). The $\mathrm{pH}$ (post feeding) falls within the range reported to be suitable for fibre digestion and optimum microbial protein synthesis (Thomas et al., 1994), but higher when compared to 6.1 , below which cellulosis is inhibited (Mould and Orskov, 1983). The drop in $\mathrm{pH}$ post feeding is an indication of high level of fermentation of the diets, which leads to high production of VFA, which in turn had a reducing effect on $\mathrm{pH}$. This observation is in agreement with earlier reports (Adegbola, 2002; Oddoye et al., 2005). Rumen ammonia-N (RAN) concentration before feeding ranged from $21.5 \mathrm{mg} / 100 \mathrm{ml}$ for rams fed $\mathrm{CSC} / \mathrm{SDBL}$ in diet to $31.5 \mathrm{mg} / 100 \mathrm{ml}$ for those on urea/SDBL diet. There was a 
general increase in the concentrations of RAN with time. Rams fed urea $(37.5 \mathrm{mg} / 100 \mathrm{ml})$ and urea/SDBL $(34.2 \mathrm{mg} / 100 \mathrm{ml})$ diets had the highest
$(\mathrm{P}<0.001)$ RAN concentrations 3 hrs after feeding, while those on the other diets recorded the lowest.

Table 5. The $\mathrm{pH}$, rumen ammonia-N and total volatile fatty acids concentrations of rumen fluid of Yankasa rams fed urea and/or sundried broiler litter as a partial or complete replacement for cotton seed cake.

\begin{tabular}{|c|c|c|c|c|c|c|}
\hline SEM & CSC/SDBL & CSC/Urea & Diets Urea/SDBL & Urea & CSC & Time \\
\hline \multicolumn{7}{|c|}{ pH } \\
\hline 0.08 & 7.5 & 7.5 & 7.9 & 7.4 & 7.2 & $\mathrm{BF}$ \\
\hline 0.19 & $6.9^{\mathrm{a}}$ & $6.9^{\mathrm{a}}$ & $6.4^{\mathrm{a}}$ & $6.1^{\mathrm{b}}$ & $6.2^{\mathrm{b}}$ & $3 \mathrm{hrAF}$ \\
\hline 0.07 & $7.2^{\mathrm{a}}$ & $7.2^{\mathrm{a}}$ & $7.2^{\mathrm{a}}$ & $6.8^{\mathrm{b}}$ & $6.7^{\mathrm{b}}$ & Mean \\
\hline \multicolumn{7}{|c|}{ RAN (mg/100ml) } \\
\hline 0.98 & $23.8^{b}$ & $26.7^{\mathrm{b}}$ & $33.5^{\mathrm{a}}$ & $32.4^{\mathrm{a}}$ & $25.1^{\mathrm{b}}$ & $\mathrm{BF}$ \\
\hline 1.51 & $21.5^{\mathrm{c}}$ & $24.5^{\mathrm{bc}}$ & $34.2^{\mathrm{a}}$ & $37.5^{\mathrm{a}}$ & $28.1^{\mathrm{b}}$ & $3 \mathrm{hrAF}$ \\
\hline 1.14 & $22.7^{\mathrm{c}}$ & $25.6^{\mathrm{b}}$ & $33.8^{\mathrm{a}}$ & $35.0^{\mathrm{a}}$ & $26.6^{\mathrm{b}}$ & Mean \\
\hline \multicolumn{7}{|c|}{ VFA (mmol/100ml) } \\
\hline 0.17 & $10.3^{b}$ & $9.5^{\mathrm{c}}$ & $11.0^{\mathrm{a}}$ & $9.1^{\mathrm{c}}$ & $9.4^{\mathrm{c}}$ & $\mathrm{BF}$ \\
\hline 0.22 & $13.1^{\mathrm{a}}$ & $11.4^{\mathrm{c}}$ & $11.3^{\mathrm{c}}$ & $10.5^{\mathrm{d}}$ & $12.2^{\mathrm{b}}$ & $3 \mathrm{hrAF}$ \\
\hline 0.16 & $11.7^{\mathrm{a}}$ & $10.5^{\mathrm{c}}$ & $11.1^{\mathrm{b}}$ & $9.8^{\mathrm{d}}$ & $10.8^{\mathrm{bc}}$ & Mean \\
\hline
\end{tabular}

RAN =Rumen ammonia-N, VFA $=$ Volatile fatty acids, $\mathrm{BF}=$ Before feeding, AF $=$ After feeding, $\mathrm{hr}=$ hour, $\mathrm{CSC}=$ Cotton seed cake, $\mathrm{SDBL}=$ Sundried broiler litter

Concentration of RAN varies greatly with the animal species, nutritional status, age of animal and type of diet among others. The higher RAN concentrations in all the diets with higher protein levels $(16 \% \mathrm{CP})$ as observed in this experiment are in agreement with an earlier finding (Oddoye et al., (2005). The concentration of RAN after feeding is comparable to $20 \mathrm{mg} / 100 \mathrm{ml}$ considered optimum for forage digestion (Perdock et al., 1988). This is an indication that ruminal $\mathrm{N}$ degradation were adequate across the treatments for normal rumen function and forage digestion. Total VFA concentration of rumen fluid before feeding ranged from $9.1 \mathrm{mmol} / 100 \mathrm{ml}$ for rams on urea diet to $11.0 \mathrm{mmol} / 100 \mathrm{ml}$ for those fed urea/SDBL in diet. Level of total VFA (post feeding) was generally increased across the treatments. Rams fed CSC/SDBL $(13.1 \mathrm{mmol} / 100 \mathrm{ml})$ diet had the highest $(\mathrm{P}<0.001)$ concentration, while those on urea diet the lowest $(10.5 \mathrm{mmol} / 100 \mathrm{ml})$. These values are higher when compared to the 6.19 to 11.59 $\mathrm{mmol} / 100 \mathrm{ml}$ reported for Yankasa sheep fed urea-treated or untreated rice straw with supplements containing cotton seed cake, maize bran and sundried or ensiled poultry litter (Ngele, 2008). Level of VFA post feeding may have resulted from more active digestion of fibre in the diets, which may support the hypothesis (Lee et al., 1990) that increased level of RAN results in an increased amount of energy from the diets.

\section{Conclusion}

It was concluded from this study that diets containing urea and CSC/urea fed to Yankasa sheep gave results comparable to those fed cotton seed cake (control), which are better than for those fed sundried broiler litter-based diets in terms of digestible nutrients intake, positive nitrogen balance and production of adequate rumen ammonia-N. However, rams fed CSC/SDBL had a better concentration of total volatile fatty acids of rumen fluid after feeding. 


\section{Acknowledgement}

The authors wish to thank the Abubakar Tafawa Balewa University, Bauchi, Nigeria, for their support in this study.

\section{References}

Abebe, G., R. C. Merkel, G. Animut, T. Sahlu and A. L. Goetsch. 2004. Effects of ammoniation of wheat straw and supplementation with soyabean meal or broiler litter on feed intake and digestion in yearling Spanish goat wethers. Small Rum. Res. 51:37-46.

Adamu, A. M., I. F. Adu, S. A. S. Olorunju, C. B. I. Alawa, and O. S. Lamidi. 1996. Effects of ureaammoniation and cotton seed cake supplementation on the utilization of sorghum stover by sheep. Niger. J. Anim. Prod. 23(2):147-152.

Adegbola, T. A. 1998. Sustainable ruminant production for human nutrition and national development. Inaugural lecture series No. 7 Abubakar Tafawa Balewa University. Abubakar Tafawa Balewa University Press, Bauchi Nigeria pp.44.

Adegbola, T. A. 2002. Nutrient intake, digestibility and rumen metabolites in bulls fed rice straw with or without supplements. Niger. J. Anim. Prod. 29(1):40-46

Adeloye, A. A. and J. O. Fasetan. 1997. The influence of supplements of cotton seed cake on the utilization of sorghum glume by goats. Niger. J. Anim. Prod. 24(2):150-154.

Adu, I. F. and C. A. M. Lakpini. 1983. The utilization of dried poultry waste as protein supplement for growing
Yankasa sheep. Niger. J. Anim. Prod. 3(1):49-56.

AOAC 1990. Official Methods of Analysis. $15^{\text {th }}$ Edition Association of Official Analytical Chemists, Arlington, VA.

Chen, X. B. and M. J. Gomes. 1992. Estimation of microbial protein supply to sheep and cattle based on urinary excretion of purine derivatives. An overview of the technical details. International Feed Resources Unit, Rowette Research Institute, Bucksburn, Aberdeen AB2 95B, UK. Occasional Publications. pp.1-20.

Chesworth, J. 1992. Ruminant Nutrition. Macmillan Press, China. pp.170.

Goering, H. K. and P. J. Van Soest. 1970. Forage Fibre Analysis (apparatus reagent, procedures and some applications). Agricultural Handbook 379 of Agricultural Research Services, U.S. Department of Agriculture, U.S. Government Printing Office, Washington DC.

Kozloski, G. V., L. M. BonnecarrereSanchez, R. L. Cadorin-Jr, M. V. Reffatti, D. Perez-Neto, and L. D. Lima. 2006. Intake and digestion by lambs of dwarf elephant grass (Pennistum purpureum Schum. CV Mott) hay or hay supplemented with urea and different levels of cracked corn grain. Anim. Feed Sci. Tech. 125:111-121.

Kozloski, G. V., H. M. N. Ribeiro-Filho and J. B. Rocha. 2000. Effect of the substitution of urea for soyabean meal on digestion of steers. Canad. J. Anim. Sci. 80:713-719.

Lee, G. C., D. W. Hennessy, P. J. Williamson, J. V. Nolan, R. J. 
Kempton and R. A. Leng. 1990. Response to protein meal supplements by lactating beef cattle given a low quality pasture. Austr. J. Agric. Res. 36:729-734.

Leng, R. A. 1990. Factors affecting utilization of poor quality forages by ruminants particularly under tropical conditions. Nutr. Res. Rev. 3:277303.

Mgheni, D. M., A. E. Kimambo, F. Sundstol and J. T. Madsen. 1994. The influence of urea supplementation on treated rice straw and fishmeal supplementation on rumen environment and activity in sheep. Anim. Feed Sci. Tech. 49:223235.

Mould, F. L. and E. R. Orskov. 1983. Manipulation of rumen fluid $\mathrm{pH}$ and its influence on cellulolysis, in sacco dry matter degradation and the rumen microflora of sheep offered either hay or concentrate. Anim. Feed Sci. Tech. 10:1-14 .

Murthy, K. S., M. R. Reddy and G. V. N. Reddy. 1996. Nutritive value of supplements containing poultry droppings/litter for sheep and goats. Small Rum. Res. 21:71-75.

Ngele, M. B. 2008. Fermentation and metabolic trends in rams fed roughages with various supplements. $\mathrm{PhD}$ Thesis, Abubakar Tafawa Balewa University, Bauchi, Nigeria.

Oddoye, E. O., K. Amaning-Kwarteng, E. K. Awotwi and J. E. Fleischer. 2005. In sacco degradability of grass and hay and rumen characteristics in sheep fed urea ammoniated rice straw or untreated supplemented rice straw. Bull. Anim. Health Prod. Afr. 53(2):113-123
Osuhor, C. U., I. F. Adu and N. N. Umunna. 1991. Growth response of Yankasa sheep fed different levels of concentrate supplementation. Niger. J. Anim. Prod. 18:20-24.

Pan, J., T. Suzuki, S. Koike, K. Ueda, Y. Kobayashi, K. Tanaka and M. Okubo. 2003. Effects of urea infused into the rumen on liquid and particle associated fibrolytic enzyme activities in steers fed low quality grass hay. Anim. Feed Sci. Tech. 104: 13-27.

Perdock, H. B., R. A. Leng, S. H. Bird, G. Habib and M. Van Houtert. 1988. Improving livestock production from straw-based diets. In: E. F. Thomas, and F. S. Thomson (Eds.). pp. 81-91. Increasing small ruminant productivity in semi arid areas. International Centre for Agricultural Research in dry areas, Syria.

Rankins, D. L., J. T. Eason, T. A. McCaskey, A. H. Stephenson, J. G. Floyd Jnr. 1993. Nutritional and toxicological evaluation of three deep stacking methods for the processing of broiler litter as a feedstuff for beef cattle. Anim. Prod. 56:321-326.

Smith, L. W. and W. E. Wheeler. 1979. Nutritional and Economic value of excreta. J. Anim. Sci. 48:144-156.

SAS. 2000. Users Guide Statistics. Version 8.2. SAS Institute Incorporated, Cary, New York, USA.

Steel, R. G. D. and J. H. Torrie. 1980. Principles and procedures of statistics. $2^{\text {nd }}$ edition McGraw-Hill Incorporated, Tokyo, Japan pp.633.

Thomas, V. M., C. K. Clark and C. M. Schuldt. 1994. Effect of substituting feather meal for soyabean meal on ruminal fibre fermentation and lamb 
Emir. J. Food Agric. 2010. 22 (4): 298-307

http://ffa.uaeu.ac.ae/ejfa.shtml

and wool growth. J. Anim. Sci. 72:509-514.

Ziolecki, A. and E. Kwaitkowska. 1975.

Gas chromatography of C1- C5 fatty acids in rumen fluid and fermentation media. J. Chromatograph. 80:31253132 . 